\title{
Difference of Science Process Skills and Learning Activity in Guided Inquiry and Direct Instruction
}

\author{
Anna Juniar ${ }^{1}$, Ratih Dwi Fardilah², Pravil M. Tambunan ${ }^{3}$ \\ ${ }^{1}$ Doctoral Student of Chemistry Education, Universitas Negeri Medan, Indonesia \\ ${ }^{2}$ Department of Chemistry Education, Universitas Negeri Medan, Indonesia \\ ${ }^{3}$ Department of Pharmacy, University of Tjut Nyak Dhien, Medan City, Indonesia \\ *anna.juniar@ymail.com
}

\begin{abstract}
This study aims to determine the differences in science process skills and learning activities of students who are taught using the Guided Inquiry model and Direct Instruction integrated by practicum on colligative nature of electrolyte solutions. The sample was determined through purposive sampling technique, by taking 2 classes (XII MIA-1 as the experimental class-I which applied Guided Inquiry and XII MIA-2 as the experimental class-II which applied Direct Instruction. The data collection was done by pre-test and post-test for learning outcome with 20 multiple choice tests and for science process skills with six essay test. The results showed that there were differences in the average value of science process skills with t-count $>$ t-table were $8.76>2.0345$, while the difference in the average value of learning attitude were 88.54 (Very Good) and 77.43 (Good).
\end{abstract}

Key words: Guided Inquiry, Learning Activity, Scientific Process Skills

\section{Introduction}

One of the problems that happen in the world of education is the low quality of education in Indonesia. This is due to the weakness of learning process in education. Improving of the quality of chemistry learning can be done by the teacher through a variety of ways, one of the right ways are emphasize the student's skill for mastering science as a process not just as a product. At this time chemical learning still emphasizes the product not the process. Even though, the good treatment for mastering science to student will produce good products [1].

Chemistry cannot be separated from scientific approach process [2]. Good mastery of chemical learning can be realized through science process skills [3]. Science process skills are procedural, experimental, and systematical skills of science as the basis of science and investigate the habits of scientific thought or the ability of scientific inquiry $[4,5,6]$. For this reason, it is important for chemistry teachers to have a good understanding of science process skills. Student who studies chemistry is to remember and understand the chemical concepts that had found by scientists. In fact, student can behave like a scientist in discovering the concepts of chemical. Students use the science process skills as basic skills to master chemistry [7].

Science process skills can be developed in a scientific approach-based learning [3]. Besides science process skills, student's learning activities needs to be improved in the learning process. Learning activities are various activities that are given to student in teachinglearning situations with the aim that student get the specified content so that curriculum 
objectives can be achieved [8]. The most appropriate learning model for applying science process skills and activating student learning activities is the Guided Inquiry learning model.

Guided Inquiry is a learning model that can improve understanding of scientific concepts. Beside that it can increase student's mastering process in learning because they are involved in conducting investigations through practical activities. Teacher will guide their student for applying the real experiment, repair, classify, predict and communicate [7].

The Guided Inquiry learning model can enable student to move step by step in the chemistry learning process because students are guided to understand coherent processes, starting from problems, hypotheses, formulating problems, collecting data, results, and drawing conclusions under the guidance of teacher [3].

The Guided Inquiry learning model can overcome problems about the weakness of science process skills and learning activity. The advantages of learning inquiry models: Firstly, increase student's motivation to learn and give students the opportunity to think carefully about ideas, problems, and questions. Secondly, provide opportunities for students to participate fully that will increase their curiosity in scientific field inside or outside the classroom. Thirdly, encourage students to have a spirit of initiative, patience, cooperation, unity, and making the decision. Student capabilities will improve to understand about science process skills, conceptual understandings, and relationships, and knowledge that enable them to explore in the real social environment $[9,10,11]$.

Guided Inquiry is the right learning model to develop complete cognitive, affective and psychomotor aspects including learning models that are in line with the development of modern learning [12]. In fact, there are other models that can be applied practicum methods as Guided Inquiry model. This appropriate learning model is Direct Instruction integrated by practicum.

\section{Research Method}

\section{General background of research}

This research was conducted at Senior High School-5 Binjai in North Sumatra, Indonesia. Samples from this study were students of class XII MIA-1 and XII MIA-2 with 33 students in each class. The effectiveness of the Guided Inquiry learning model and Direct Instruction integrated by practicum implemented the practicum worksheets for students which had adjusted to each learning model. Statistical tests carried out included the normality test, homogeneity test and two-party t-test. The pretest value of science process skills was analyzed further using Alpha Cronbach's validation. Finally 6 test essay questions were valid and reliable in science process skills. After a statistical test, it was found that the question was normal and homogeneous. The next step after being given treatment in the form of different learning models, both classes implemented final test so that the results of the post-test were obtained.

\section{Sample of research}

The population of this study was all students of class XII IPA at SMAN 5 in school year's 2018/2019 as many as 206 students divided into six classes. The sample in this study was taken using a purposive sampling technique. The researcher determines the sample to be examined directly. The researcher deliberately determines the sample members because there are things to consider. The two classes are taught with the same teacher and the duration of 
study was same but different study schedules. Samples which taken were 2 classes, XII MIA1 class as the experimental class-I taught used the Guided Inquiry learning model and XII MIA-2 class as the experimental class-II taught by Direct Instruction integrated by practicum learning model.

\section{Instrument and procedures}

The test method was carried out twice, the pre-test and post-test (as the test instrument) and observation sheet of learning activities (as the non-test instrument). The form of the test used problem descriptions (essay) compiled based on 6 indicators of science process skills which consist of student's skills in observing, grouping, formulating problems, designing experiments, formulating hypotheses and interpreting. While to measure the score of science process skills, essay test was consisting of 6 questions with assessments ranging from 20-15 each item questions answered right. The measure for learning activities used observation sheet with 6 indicators and 8 aspects and assessment ranging from 1-4 each aspect of learning activities.

\section{Data analysis}

Data analysis techniques for scientific process skill's carried out include: tests of normality, homogeneity, and t-test of two parties. All of the tests were carried out in the experimental class-I and experimental class-II so that there could be a difference in the distribution of the results of normality, homogeneity and t-test values of the two parties in both classes. The data analysis for learning activities used descriptive analysis techniques during student learning activities in the both classes.

\section{Results and Discussion}

\section{Validity of Science Process Skills}

The application of science process skill question and observation sheet of student learning activities in the Guided Inquiry model and Direct Instruction have involved two expert validators consisting of one professor and one doctoral degree. The results of validation, reliability and level of difficulty and different power of each component of the science process skill indicators as shown in Table 1. As for the reliability, each component of the content validity is also reliable.

Table 1. Results of Analysis the Science Process Skill Test Instrument

\begin{tabular}{clccccc}
\hline No & \multicolumn{1}{c}{$\begin{array}{c}\text { Indicator } \\
\text { of SPS }\end{array}$} & $\begin{array}{c}\text { Vali- } \\
\text { dity }\end{array}$ & $\begin{array}{c}\text { Different } \\
\text { Power }\end{array}$ & $\begin{array}{c}\text { Level of } \\
\text { Difficulity }\end{array}$ & Reliability & Information \\
\hline 1 & Applying Concept & Valid & Accepted & Medium & & Used \\
2 & Interpreting & Valid & Accepted & Medium & reliability was & Used \\
3 & Observing & Valid & Accepted & Medium & very high & Used \\
4 & Grouping & Valid & Accepted & Medium & & Used \\
5 & Designing & Valid & Accepted & Medium & $r_{11}=0.822$ & Used \\
& Experiment & & & & & \\
6 & Making Hypothesis & Valid & Accepted & Medium & & \\
\hline
\end{tabular}




\section{Data Analysis of Research Results}

Based on the results of calculations, statistical data obtained from science process skills of students in experimental class-I and experimental class-II are summarized in Table 2.

Table 2. Differences of Scientific Process Skill's Student

\begin{tabular}{lllllll}
\hline \multicolumn{1}{c}{ Class } & \multicolumn{2}{c}{ Average Score } & \multicolumn{2}{c}{ Deviation Standard } & \multicolumn{2}{c}{ Varian $\left(\mathbf{S}^{2}\right)$} \\
& Pre-test & Post-test & Pre-test & Post-test & Pre-test & Post-test \\
\hline Experiment I & 26.52 & 89.58 & 7.65 & 5.58 & 56.79 & 30.18 \\
Experiment II & 26.30 & 78.42 & 6.94 & 4.74 & 46.69 & 21.76 \\
\hline
\end{tabular}

The score of pre-test and post-test for experimental class- 1 and experimental class- 2 can be seen in Figure 1.

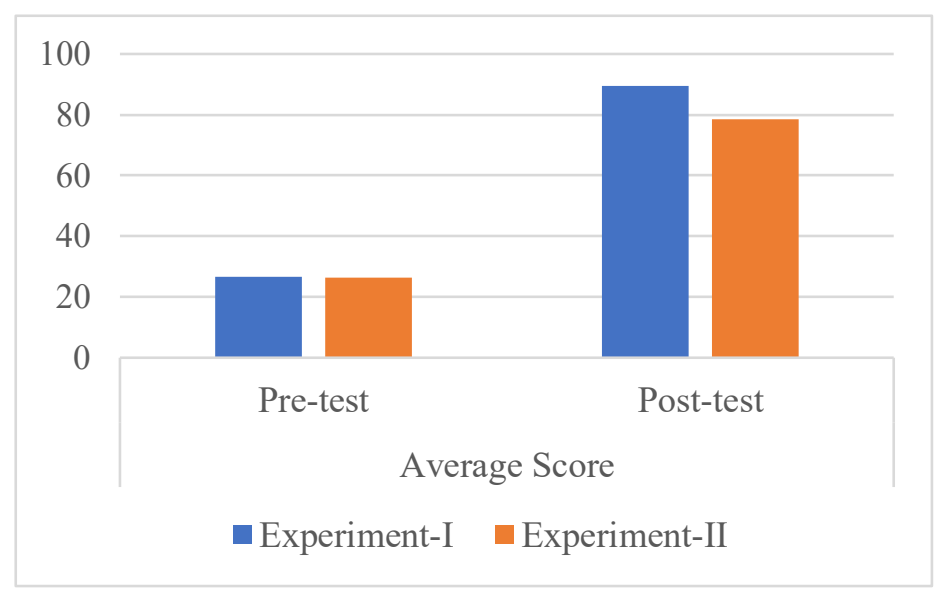

Fig 1. The score of pre-test and post-test both of experimental class

From the picture above, it can be seen that there are differences in the value of the pretest and post-test experimental class-I compared with the experimental class II. The experimental class-I has a higher pre-test and post-test value than the experiment class-II. The average value of student's initial and final abilities in the experimental class-I and experiment class-II for each item about the indicators of science process skills are shown in Table 3.

Table 3. The Average Score Each Scientific Process Skill's Indicator

\begin{tabular}{lcccc}
\hline \multirow{2}{*}{ The Indicators of SPS } & \multicolumn{3}{c}{ The Average Value Each Item } \\
\cline { 2 - 5 } & \multicolumn{2}{c}{ Experiment-I } & \multicolumn{2}{c}{ Experiment-II } \\
\cline { 2 - 5 } & Pre-test & Post-test & Pre-test & Post-test \\
\hline 1. Observing & 7.64 & 16.82 & 4.91 & 15.24 \\
2. Grouping & 4.27 & 13.79 & 4.91 & 12.97 \\
3. Applying Concept & 3.42 & 13.33 & 4.30 & 11.39 \\
4. Interpreting & 5.03 & 14.24 & 4.76 & 14.45 \\
5.Designing Experiment & 2.76 & 17.33 & 3.54 & 11.12
\end{tabular}


There were differences in the mean values of the pre-test and post-test in the experimental class I and experimental class-II for each item in the indicator of science process skills. From the results of the pre-test and post-test the science process skills of the students described per indicator showed that the initial abilities of the two sample groups were almost the same. The pre-test results showed that indicators of science process skills such as interpreting, conducting experiments, formulating hypotheses in experimental class-I were higher than experimental class II, while indicators observed, grouped and applied concepts to experimental class II students higher than experimental class-I.

After being given treatment in the form of two different learning models in the both of classes, different final results (post-test) were obtained. The average value each category of science process skills questions in the experimental class-I that uses the Guided Inquiry model is higher than the experimental class-II which uses a practically integrated Direct Instruction learning model. The most obvious difference is in aspects of student's science process skills in conducting experiments. The experimental class-I students who applied the Guided Inquiry model in the SPS aspect designed the experiment to obtain a higher average score (17.33) than used Direct Instruction integrated by practicum $(11,12)$.

The score of the science process skills of the two experimental classes was then analyzed from the post-test scores of the two experimental classes given after the end of the treatment so that the differences in percentage of science process skills were obtained. The difference in percentage of science process skills of students each aspect as in Table 4.

Tabel 4. Difference in Percentage of Scientific Process Skills each Aspect

\begin{tabular}{lcc} 
Aspect of SPS & $\begin{array}{c}\text { Experiment Class-I } \\
\text { Guided Inquiry }\end{array}$ & $\begin{array}{c}\text { Experiment Class-II } \\
\text { Direct Instruction }\end{array}$ \\
\hline 1. Applying Concept & $84.09 \%$ & $76.21 \%$ \\
2. Interpreting & $91.92 \%$ & $86.46 \%$ \\
3. Observing & $88.89 \%$ & $75.96 \%$ \\
4. Grouping & $94.49 \%$ & $72.73 \%$ \\
5. Designing Experiment & $86.67 \%$ & $72.73 \%$ \\
6. Making Hypothesis & $93.74 \%$ & $85.66 \%$ \\
\hline
\end{tabular}

Based on Table 4, the illustrated for the science process skill's difference as has been shown in Figure 2. 


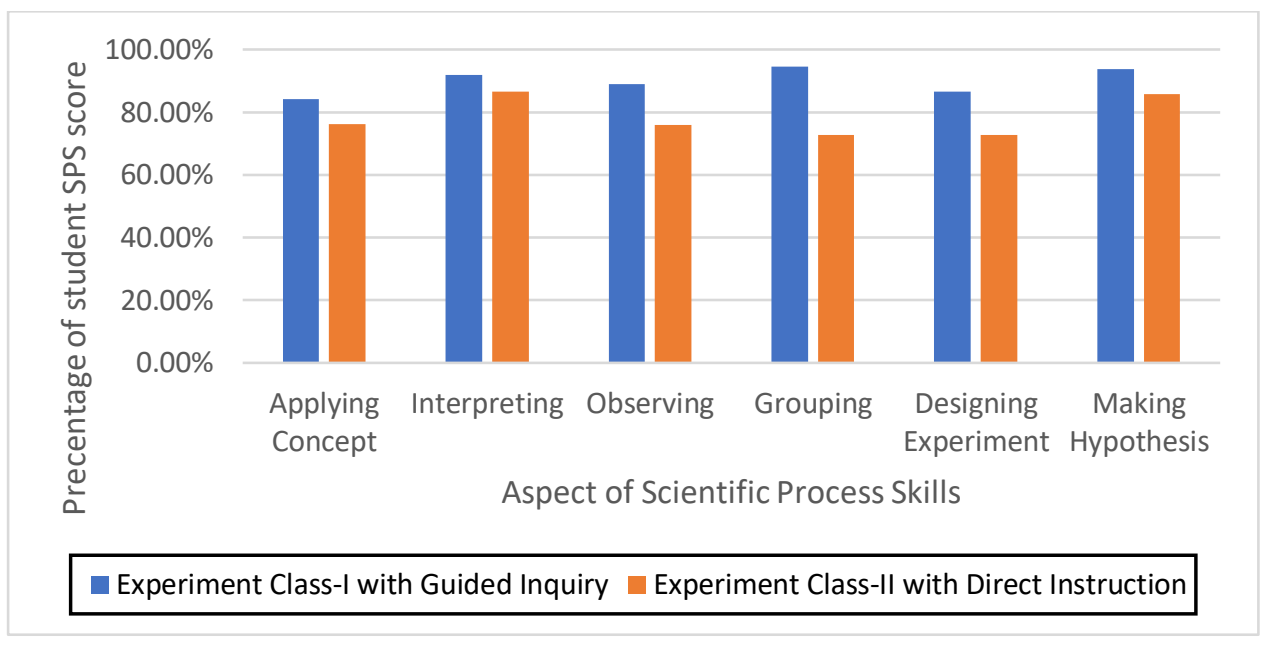

Fig 2. Differences in Presentation of Student's Science Process Skills

\section{Analysis of Differences in Activities and Attitudes of Student Learning}

To analyze differences in science process skills, in this study also carried out an assessment of differences in student learning activities. The assessment of student learning activities was carried out by three observers by filling in the observation sheet during the learning process taking place in the two experimental classes. The average value result of student learning activities obtained in the experimental class-I have been summarized in Table 5 .

Tabel 5. Tabulation of Assessment for Learning Activity in Experiment-I

\begin{tabular}{llccc}
\hline \multirow{2}{*}{ Indicator } & \multirow{2}{*}{ Observed Score } & \multicolumn{3}{c}{ Score at meeting } \\
& & I & II & III \\
\hline Readiness to Learn & Preparation of tools and materials & 91.67 & 92.42 & 91.67 \\
\multirow{2}{*}{$\begin{array}{l}\text { Skills for using tools and } \\
\text { material }\end{array}$} & Skills for use props & 84.09 & 85.61 & 84.85 \\
\multirow{2}{*}{ Team work } & Mastery of practicum procedures & 93.18 & 87.88 & 88.64 \\
& Timeliness for making observation & 88.64 & 89.39 & 89.39 \\
\multirow{2}{*}{ Work in group } & Solidarity in one team & 92.42 & 89.39 & 88.64 \\
& The timeliness of the team completing the & 84.09 & 87.88 & 85.61 \\
Make conclusion & practicum & & & \\
& Cleanliness of the place and laboratory tools & 87.88 & 90.15 & 86.36 \\
\hline
\end{tabular}

To analyze differences in science process skills, in this study also carried out an assessment of differences in student learning activities. The assessment of student learning activities was carried out by three observers by filling in the observation sheet during the learning process taking place in the two experimental classes. The three observers assessed student learning activities based on the achievement of five indicators adjusted to eight aspects of student learning activities.

Based on the assessment, the results showed that all student learning activities had met the five indicators in the category of "Very Good" for three meetings. The average value of 
student learning activities indicator obtained on the enthusiasm are 91.92; the indicator of skill for using laboratory tools is 87.80 ; the cooperation is 90.15 ; the group employment is 87.00 and the indicator concludes is 87.80 .

The results of the research before, it obtained the achievement of the value of learning activities of students who were taught using the Guided Inquiry learning model in the first cycle of $100 \%$. This proves that the Guided Inquiry model is very effective used to improve student learning activities, by showing better results than using a practically Direct Instruction integrated by practicum.

The student learning activities carried out in the experimental class-II in 3 meetings, the results showed that only five indicators get "Good" categories. The average value of student learning activities indicators obtained on the enthusiasm is 75.00 with "Good" category with the observed aspects being students' readiness in preparation of tools and materials (75.00). The results of the assessment of student learning activities obtained as in Table 6 .

Table 6. Tabulation of Assessment for Learning Activity in Experiment-II

\begin{tabular}{|c|c|c|c|c|c|c|c|}
\hline \multirow{2}{*}{ Indicator } & \multirow{2}{*}{ Aspects } & \multicolumn{3}{|c|}{ Score each Meeting } & \multirow[t]{2}{*}{ Average } & \multirow{2}{*}{$\begin{array}{c}\bar{X} \text { each } \\
\text { Indicator }\end{array}$} & \multirow[t]{2}{*}{ Criteria } \\
\hline & & I & II & III & & & \\
\hline $\begin{array}{l}\text { Readiness to } \\
\text { Learn }\end{array}$ & Preparation of tools & 75 & 74.24 & 75.76 & 75 & 75.00 & Good \\
\hline \multirow{3}{*}{$\begin{array}{l}\text { Skills for using } \\
\text { tools and } \\
\text { material }\end{array}$} & $\begin{array}{l}\text { Preparation of } \\
\text { chemical material }\end{array}$ & 72.73 & 70.45 & 70.45 & 71 & \multirow{3}{*}{73.43} & \multirow{3}{*}{ Good } \\
\hline & Skills for use props & 74.24 & 73.48 & 71.21 & 73 & & \\
\hline & $\begin{array}{l}\text { Timeliness for } \\
\text { observation }\end{array}$ & 78.03 & 73.76 & 76.52 & 76 & & \\
\hline \multirow[t]{2}{*}{ Team work } & $\begin{array}{l}\text { Solidarity in one } \\
\text { team }\end{array}$ & 78.03 & 78.03 & 83.33 & 80 & 79.80 & Good \\
\hline & $\begin{array}{l}\text { The timeliness of the } \\
\text { team completing the } \\
\text { practicum }\end{array}$ & 81.06 & 77.27 & 81.82 & 80.1 & \multirow{2}{*}{81.69} & \multirow{2}{*}{ Good } \\
\hline Work in group & $\begin{array}{l}\text { Cleanliness } \\
\text { laboratory tools } \\
\text { instrument }\end{array}$ & 85.61 & 82.58 & 81.82 & 83.4 & & \\
\hline $\begin{array}{l}\text { Make } \\
\text { conclusion }\end{array}$ & $\begin{array}{l}\text { Apply the right } \\
\text { conclusion in } \\
\text { laboratory report }\end{array}$ & 86.36 & 81.82 & 82.58 & 83.6 & 83.59 & Good \\
\hline
\end{tabular}

The analysis assessment result of student learning activities in the two experimental classes as in Tables 6 and 7, graphs of the difference in achievement of the five indicators of student learning activities in the experimental classes I and II as in Figure 3. 


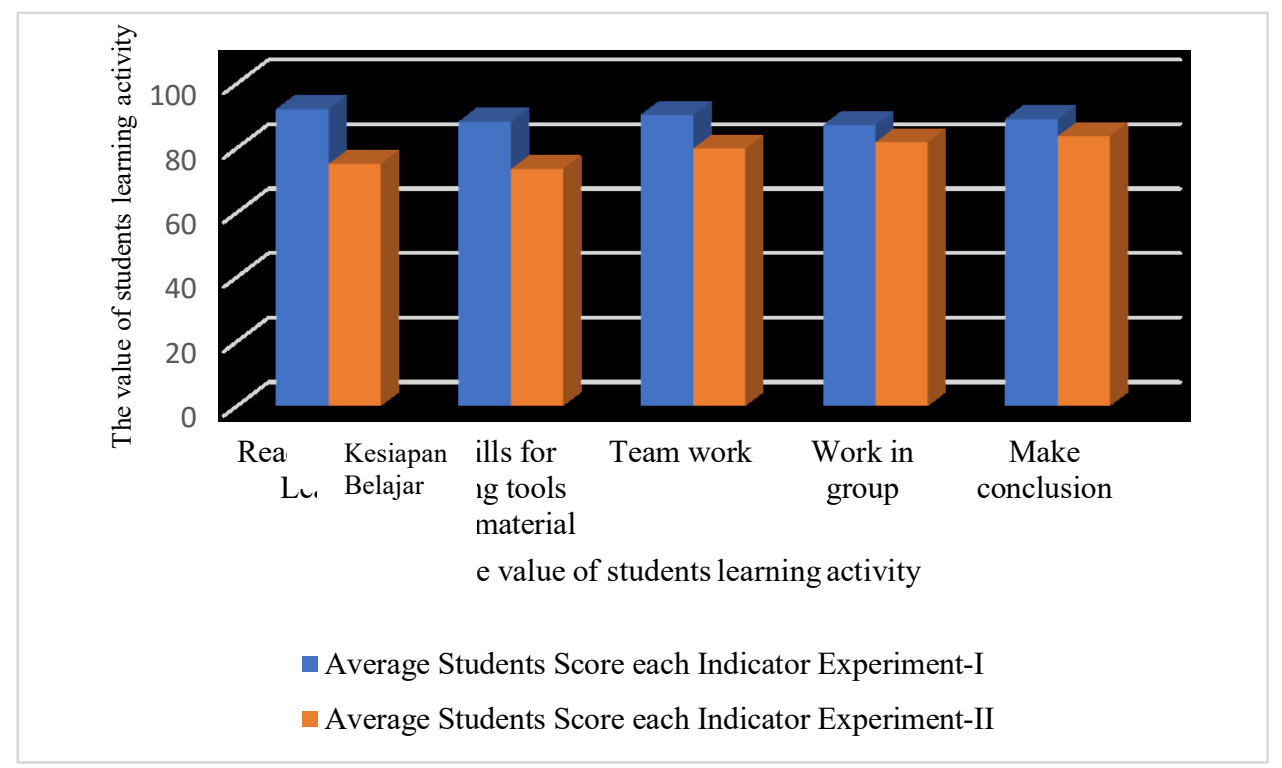

Fig 3. The Differences in the Score of Student Learning Activities

The value obtained on the indicator of the skill using practicum tools is 73.43 with "Good" category with the observed aspects being the skill of using props (71.21) while the mastery of practicum procedures (72.98). The value obtained in the cooperation indicator is 79.80 under the "Good" category with the observed aspect being group collaboration in one team (79.80). The value obtained in the group work indicator is 81.69 under the "Good" category with the observed aspects being the timeliness of the team completing the practicum (80.05). The cleanliness of the place and practicum (83.34) and the indicator concludes the value obtained is 83.59 with "Good" category.

\section{Discussion}

The average value of science process skills (post-test) of students in the experimental class I was 89.58 while in the experimental class II was 78.424 . These results indicate that the experimental class I taught using the Guided Inquiry learning model was better than the experimental class II which was taught by the practically integrated Direct Instruction model.

The high average science process skills in the experimental class I was because in the experimental class students were taught the Guided Inquiry model. These results occur because through the Guided Inquiry model, students allow learning through simple experimental activities by applying aspects of science process skills in it, so that the improvement of science process skills is very possible to be achieved through a practically integrated Guided Inquiry model. In this learning model students have a wide opportunity to observe, classify, plan experiments and hypothesize under the guidance and direction of the researcher. In addition, students who are taught with the Guided Inquiry model are used to working in teams when in class so students will easily communicate and cooperate during the practicum. 
Based on the results of the study, it can be seen that learning with guided inquiry models is very suitable to be used to improve student learning attitudes. This is because the guided inquiry model provides opportunities for students the opportunity to find concepts or information independently under the guidance of the teacher. Students are guided to formulate problems, and carry out practical work independently to find concepts in learning.

A series of simple experimental activities carried out by students have been able to encourage curiosity, confidence and foster students' learning attitudes so that the three indicators of learning attitudes namely cognition, affection and konasi can be realized. The learning process by applying a guided inquiry learning model is also able to improve students' scientific attitudes because this model gives students the flexibility to also be able to think critically and actively participate in the class.

This is supported by recent research, suggesting that guided inquiry learning models can improve scientific attitudes and learning outcomes of students in class XI MIPA 3 Surakarta Public High School 5 in the 2015/2016 school year [11].

\section{Conclusions}

The Guided Inquiry teaching model is designed to improve science process skills and student learning outcomes. The implication of this study is that the Guided Inquiry teaching model can be an innovative solution to improve students' science process skills, because all students get the opportunity to make concept discoveries through simple experiments like a scientist. The implications of the success of students' science process skills can be observed through increasing student learning attitudes while studying the concept of colligative properties of solutions in the class. After treatment, there are significant differences between students who are taught with guided inquiry models and practicum-based Direct Instruction. The difference in the results of the science process skills of the students learned using the Guided Inquiry model and practicum Direct Instruction on the material of the colligative nature of the electrolyte solution, based on the results of hypothesis analysis using the twoparty t-test found that tcount $>\mathrm{t}$ table is $8.761>2.035$. Differences in learning attitudes of students who are taught using the Guided Inquiry model and practically integrated Direct Instruction on the material of the colligative nature of the electrolyte solution with a value of 88.54 (Very Good) and 77.43 (Good). Subsequent research on science process skills and student learning attitudes using different indicators is expected to explore the usefulness of science process skills to be applied in high schools to improve learning innovation in Indonesia.

\section{References}

[1] Utami, B., Yamtinah, S., Saputo, S., Haryono \& Akbar, R.R. Science Process Skills in Senior High School Students-Class XI with Salt Hydrolysis Material. National Seminar on Chemistry and Chemical Education VIII. (2016).

[2] Limatahu,I., Sutoyo, W.S \&Prihani, B.K. Development Of Ccdsr Teaching Model To Improve Science Process Skills Of Pre-Service Physics Teachers. Journal of Baltic Sci Edu. 17 (5): 812-827 (2018). 
[3] Irwanto, I., Rohaeti, E dan Prodjosantoso, A,K. Undergraduate Students' Science Process Skills In Terms Of Some Variables: A Perspective From Indonesia, Journal of Baltic Sci Edu. 17(5): 751- 764 (2018).

[4] Dogan, I., \& Kunt, H. Determination of Prospective Preschool Teachers' Science Process Skills. Journal of European Edu. 6 (1), 32-42 (2016).

[5] Suyidno, Nur, M., Yuanita, L., Prahani, B. K., \& Jatmiko, B. Effectiveness of creative responsibility-based teaching (CRBT) model on basic physics learning to increase student's scientific creativity and responsibility. Journal of Baltic Science Education. 17 (1), 136-151 (2018).

[6] Zeidan, A. F., \& Jayosi, M. R. Science process skills and attitudes toward science among Palestinian. World Journal of Education, 5 (1), 13-24 (2015).

[7] Prayitno, B. A., Corebima, D., Susilo, H., Zubaidah, S., \& Ramli, M. Closing the science process skills gap between students with high and low-level academic achievement. Journal of Baltic Science Education. 16 (2), 266-277 (2017).

[8] Alkan, F. Experiential learning: Its effects on achievement and scientific process skills. Journal of Turkish Science Education. 13 (2), 15-26 (2016).

[9] Arabacioglu, S., \& Unver, A. O. Supporting inquiry-based laboratory practices with mobile learning to enhance students' process skills in science education. Journal of Baltic Science Education. 15 (2), 216-230 (2016).

[10] Berg, C. A. R., Bergendahl, V. C. B., \& Lundberg, B. K. S. Benefiting from an openended experiment? A comparison of attitudes to, and outcomes of, an expository versus an open-inquiry version of the same experiment. International Journal of Science Education. 25 (3), 112-121 (2003).

[11] Dewi, N. I., Poedjiastoeti, S., \& Prahani, B. K. ELSII learning model based local wisdom to improve students' problem-solving skills and scientific communication. International Journal of Education and Research. 5 (1), 107-118 (2017).

[12] Malihah., M. The Influence of Guided Inquiry on Student Chemistry Learning Outcomes on the Reaction Rate Concept. Thesis. Syarif Hidayatullah UIN. Jakarta (2014).

[13] Fajariyah., Astuti,Y., Santoso,J. Perbedaan model pembelajaran inkuiri terbimbing (guided inquiry) dan Direct Instruction terhadap Keterampilan Proses Sains Peserta Didik pada Materi Sifat Koligatif Larutan di SMA Negeri 02 Samarinda. Jurnal Pendidikan. 8(1) (2016).

[14] Jatmiko, B., Prahani, B. K., Munasir, Supardi, Z. A. I., Wicaksono, I., Erlina, N., Pandiangan, P., Althaf, R., \& Zainuddin. The comparison of OR-IPA teaching model and problem-based learning model effectiveness to improve critical thinking skills of preservice physics teachers. Journal of Baltic Science Education, 17 (2), 1-22 (2018).

[15] Nurkhamid. Pengaruh Pembelajaran CTL dengan Model Inkuiri Bebas Termodifikasi dan Inkuiri Terbimbing terhadap Prestasi Belajar Siswa Ditinjau dari Kreativitas Siswa dan Kemampuan Verbal. Tesis. FKIP Universitas Sebelas Maret. Surakarta (2016).

[16] Purwati, N., Zubaidah, S., Corebima, A.D., dan Mahanal,S. Increasing Islamic Junior High School Students Learning Outcomes through Integration of Science Learning and Islamic Values, International Journal of Instruction, 11(4): 841-854 (2018). 
[17] Suyidno, Nur, M., Yuanita, L., \& Prahani, B.K. Validity of creative responsibility-based learning: An innovative physics learning to prepare the generation of creative and responsibility. Journal of Research \& Method in Education. 7 (1), 56-61 (2017).

[18] Varadela, I.A. The Influence of Guided Inquiry Based Practicum Methods in the Help of Practical Workload on Students' Science Process Skills. Thesis. FMIPA Semarang State University. Semarang (2016).

[19] Widyaningsih, S. W., Rismawati, R., Sinon, I. L., \& Yusuf, I. The application of guided inquiry models to science process skills of students at Manokwari State Vocational High School 02. Lectura: Jurnal Pendidikan. 8 (1) (2017). 